\title{
Hubungan derajat kolesteatoma dengan keberhasilan operasi mastoidektomi radikal pada penderita otitis media supuratif kronis
}

\author{
Edi Handoko, Dyah Indrasworo, Akhmad Harun Nur Salim \\ Departemen Ilmu Kesehatan Telinga Hidung Tenggorok-Bedah Kepala Leher \\ Fakultas Kedokteran Universitas Brawijaya/ RSUD dr.Saiful Anwar \\ Malang
}

\begin{abstract}
ABSTRAK
Latar belakang: Mastoidektomi radikal merupakan salah satu terapi pembedahan pada Otitis Media Supuratif Kronis(OMSK) dengan kolesteatoma. Kolesteatoma dapat diklasifikasikan melalui sistem TMC (tympanum-mastoid-complication). Telinga yang kering merupakan indikator keberhasilan operasi. Tujuan: Penelitian ini bertujuan untuk mengetahui hubungan antara derajat kolesteatoma pada penderita OMSK dengan kolesteatoma, dengan keberhasilan operasi. Metode: Penelitian ini menggunakan desain analitik deskriptif dengan melibatkan 14 penderita OMSK dengan kolesteatoma, yang menjalani mastoidektomi radikal di RSUD Dr. Saiful Anwar Malang periode 1 Januari 2017-31 Desember 2018. Derajat kolesteatoma dinilai dari pemeriksaan otoskopi dan/ atau mikroskopi, pemeriksaan foto Schuller, dan temuan operasi. Keberhasilan operasi dilihat dari telinga kering saat evaluasi 2 bulan pasca operasi. Analisa statistik yang digunakan adalah uji Kolmogorov Smirnov dan Mann Whitney. Hasil: Evaluasi hasil mastoidektomi radikal antara derajat kolesteatoma 3 dan 4 memiliki perbandingan frekuensi yang sama dengan $p=1,00(>0,05)$. Hasil operasi telinga kering adalah $85,6 \%$ dan basah $14,4 \%$. Kesimpulan: Keberhasilan operasi mastoidektomi radikal tidak memiliki hubungan yang signifikan dengan derajat kolesteatoma pada penderita OMSK.
\end{abstract}

Kata kunci: OMSK dengan kolesteatoma, derajat kolesteatoma, keberhasilan mastoidektomi radikal

\begin{abstract}
Background: Radical mastoidectomy is one of surgery procedures for managing Chronic Suppurative Otitis Media (CSOM) with cholesteatoma. Cholesteatoma is classified into TMC (tympanum-mastoidcomplication) staging system. Dry ear is an indicator of a successful surgery. Objective: To find out the correlation between the degree of cholesteatoma in CSOM patients with cholesteatoma, and successful radical mastoidectomy. Methods: This study used a descriptive analytic design involving 14 CSOM patients with cholesteatoma who underwent radical mastoidectomy in Dr. Saiful Anwar Hospital Malang since January $1^{\text {st }}, 2017$ to December 31 $1^{\text {st }}$, 2018. The degree of cholesteatoma was assessed from otoscopy and/or microscopy, Schuller's radiologic examination, and surgical findings. Successful surgery was assessed from the dry ear after 2 months postoperative evaluation. The statistical analysis was using the Kolmogorov-Smirnov and Mann Whitney tests. Results: The outcome of radical mastoidectomy in $3 r d$ and 4 th degree cholesteatoma had the same frequency ratio with $p=1.00(>0.05)$. The results of dry ear were $85.6 \%$ and wet $14.4 \%$. Conclusions: The outcome of radical mastoidectomy surgery had no significant correlation with the degree of cholesteatoma in CSOM patient.
\end{abstract}

Keywords: CSOM with cholesteatoma, degree of cholesteatoma, radical mastoidectomy outcome 
Alamat korespondensi: Dr. dr H. Edi Handoko, Sp.T.H.T.K.L (K). Departemen Ilmu Kesehatan Telinga Hidung Tenggorok-Bedah Kepala dan Leher, Fakultas Kedokteran Universitas Brawijaya Malang. Rumah Sakit Umum Daerah Dr. Saiful Anwar, Malang. Jl. Jaksa Agung Suprapto No. 2, Klojen, Kota Malang. Email: dr.edihandoko@gmail.com.

\section{PENDAHULUAN}

Otitis Media Supuratif Kronis (OMSK) merupakan infeksi kronis di telinga tengah dengan perforasi membran timpani dan sekret yang keluar dari telinga tengah lebih dari 2 bulan, terus menerus atau hilang timbul. Sekret berupa encer atau kental, bening atau nanah. OMSK dengan kolesteatoma ditandai dengan perforasi yang letaknya marginal atau di atik, dapat mengenai tulang, disertai dengan kolesteatoma, dan sering menimbulkan komplikasi berbahaya. ${ }^{1}$

Hasil Riset Kesehatan Dasar tahun 2013 di Indonesia menunjukkan prevalensi morbiditas telinga berupa otore sebanyak $2,4 \%$ dan di provinsi Jawa Timur sebesar 2,7\%. ${ }^{2}$ Pada tahun 2017-2018, jumlah pasien OMSK di poliklinik Telinga Hidung Tenggorok-Kepala Leher (THT-KL) di Rumah Sakit Umum Daerah (RSUD) Dr. Saiful Anwar, Malang sebanyak 267, dan $46,4 \%$ berupa OMSK dengan kolesteatoma. ${ }^{3}$

Mastoidektomi radikal merupakan salah satu terapi pembedahan OMSK dengan kolesteatoma. Operasi ini dilakukan dengan cara meruntuhkan dinding posterior liang telinga, membersihkan seluruh sel mastoid di sudut sinodural, daerah segitiga Trautmann, sekitar kanalis fasialis, dan daerah telinga sekitar zigoma, kemudian membuang maleusinkus bila masih ada, stapes atau sisa stapes dipertahankan, sehingga terbentuk ruangan hasil operasi yang merupakan gabungan rongga mastoid, kavum timpani dan liang telinga. ${ }^{1}$

Kondisi telinga yang kering setelah operasi, tidak adanya kolesteatoma, dan epitelisasi yang lengkap merupakan indikator keberhasilan operasi. Penyembuhan dimulai
2-4 hari setelah operasi, epitel skuamosa pada pinggiran luka akan mulai berproliferasi dan bermigrasi melintasi pinggiran luka. Melalui aktivitas fibroblast, limfosit, dan kapiler terjadi regenerasi jaringan ikat yang juga dimulai dari pinggir luka. Nutrisi yang diperlukan untuk regenerasi ini didapat dari kapiler-kapiler di sekeliling luka. Dalam waktu 2 minggu, graft sudah dilapisi epitel skuamosa. Perubahan histopatologi jaringan mukoperiosteum kavum timpani penderita otitis media supuratif kronis yang dilakukan mastoidektomi akan kembali normal setelah 12 minggu. $^{4}$

Tujuan penelitian ini adalah untuk mengetahui hubungan derajat kolesteatoma dengan keberhasilan operasi mastoidektomi radikal pada penderita OMSK.

\section{METODE}

Penelitian ini merupakan penelitian analitik deskriptif. Sampel penelitian adalah seluruh penderita OMSK dengan kolesteatoma yang dilakukan mastoidektomi radikal di RSUD Dr. Saiful Anwar Malang, periode 1 Januari 2017-30 Desember 2018.

Besar subjek penelitian adalah 14 kasus dan diambil keseluruhan selama 2 tahun. Subjek tersebut kontrol minimal 2 bulan setelah operasi, dan memiliki data rekam medis yang lengkap sesuai variabel yang diteliti, serta tidak pernah menjalani operasi telinga yang sama sebelumnya.

Semua data yang telah terkumpul dari rekam medik, status otologi, dan status neurotologi dicatat dalam lembar pengumpul data, penelitian diproses dalam komputer dengan menggunakan perangkat lunak Statistical Package for Social Science 
20 (SPSS 20). Data deskriptif disajikan dalam bentuk tabel frekuensi distributif dan sentral tendensi. Hubungan antara derajat kolesteatoma dengan keberhasilan mastoidektomi diuji dengan menggunakan uji Chi-Square. Jika syarat tidak terpenuhi digunakan uji Fisher Exact Test. Analisis data menggunakan uji Kolmogorov Smirnov dan Mann Whitney, derajat kepercayaan 95\%, $\alpha=0,05$, bermakna bila $p<0,05$.

\section{HASIL}

Penelitian dilakukan terhadap 14 pasien OMSK dengan kolesteatoma yang menjalani operasi mastoidektomi radikal di Rumah Sakit Umum Dr.Saiful Anwar Malang, periode 1 Januari 2017 sampai 31 Desember 2018.

Distribusi jenis kelamin penderita OMSK dengan kolesteatoma yang dilakukan mastoidektomi radikal (14 orang) yaitu 6 orang laki-laki $(42,8 \%)$, dan 8 orang perempuan $(57,2 \%)$. Karakteristik sampel penelitian berdasarkan umur berkisar antara 10-56 tahun.
Berdasarkan lama otore didapatkan kasus terbanyak pada kelompok lama otore 1-5 tahun sejumlah 7 orang (50,0\%). Satu kasus terdapat kolesteatoma rekuren dan dilakukan operasi revisi mastoidektomi serta satu kasus lainnya adalah pasien dengan komplikasi abses Bezold yang ditemukan epitelisasi belum lengkap dan membaik dengan terapi konservatif.

Karakteristik sampel penelitian berdasarkan jenis perforasi membran timpani, didapatkan kasus terbanyak perforasi total 6 kasus $(42,6 \%)$.

Sebelum operasi dilakukan pemeriksaan penunjang secara radiologis dengan foto Schuller dan CT scan. Didapatkan adanya gambaran kolesteatoma sebanyak 4 penderita, gambaran sklerotik sebanyak 14 penderita dan satu penderita dilakukan CT scan karena memiliki komplikasi ekstrakranial berupa abses Bezold.

Karakteristik sampel penelitian berdasarkan sisa osikel, didapatkan kasus

Tabel 1. Karakteristik sampel penelitian berdasarkan derajat kolesteatoma

\begin{tabular}{|c|c|c|c|c|c|c|}
\hline \multirow{3}{*}{ Derajat kolesteatom } & \multicolumn{4}{|c|}{ Keberhasilan operasi } & \multirow{2}{*}{\multicolumn{2}{|c|}{ Total }} \\
\hline & \multicolumn{2}{|c|}{ Kering } & \multicolumn{2}{|c|}{ Basah } & & \\
\hline & $\mathbf{N}$ & $\%$ & $\mathbf{n}$ & $\%$ & $\mathbf{n}$ & $\%$ \\
\hline 1 & 0 & 0 & 0 & 0 & 0 & 0 \\
\hline 2 & 0 & 0 & 0 & 0 & 0 & 0 \\
\hline 3 & 6 & 42,8 & 1 & 7,2 & 7 & 50,0 \\
\hline 4 & 6 & 42,8 & 1 & 7,2 & 7 & 50,0 \\
\hline 5 & 0 & 0 & 0 & 0 & 0 & 0 \\
\hline Total & 12 & 85,6 & 2 & 14,4 & 14 & 100 \\
\hline
\end{tabular}

terbanyak yaitu kelompok sisa osikel maleus inkus stapes sejumlah 7 kasus $(50,0 \%)$.

Data derajat kolesteatoma dianalisis dengan uji Fisher Exact Test untuk mengetahui hubungan derajat kolesteatoma dengan keberhasilan mastoidektomi, menunjukkan bahwa secara statistik derajat kolesteatoma pada penderita OMSK dengan kolesteatoma yang dilakukan operasi mastoidektomi radikal tidak mempengaruhi keberhasilan operasi dengan nilai $\mathrm{p}=1,000(>0,05)$.

Pemeriksaan audiometri dilakukan sebelum operasi mastoidektomi radikal dan 2-3 bulan setelah operasi. Terdapat 14 
kasus OMSK dengan kolesteatoma yang dilakukan mastoidektomi dengan 1 kasus yang tidak memiliki data audiometri sebelum operasi, dan 2 kasus yang tidak memiliki data audiometri setelah operasi. Sampel penelitian yang memiliki data audiometri sebelum dan setelah operasi berjumlah 12 orang, yang memiliki jenis tuli yang sama sebelum dan setelah operasi. Sampel yang tidak memiliki data audiometri sebelum operasi, merupakan pasien OMSK dengan kolesteatoma dengan komplikasi abses Bezold yang tidak memungkinkan dilakukan pemeriksaan audiometri di poli Neurotologi THT-KL.

Pada penelitian ini didapatkan kasus terbanyak tuli konduksi dengan derajat sedang 6 kasus $(46,1 \%)$ sebelum operasi, dan tuli konduksi 6 kasus (50\%) dengan derajat berat 4 kasus $(33,3 \%)$ setelah operasi.

Hasil uji Spearman $(\mathrm{r}=0,408, \mathrm{p}=0,166)$ menunjukkan bahwa tidak ada hubungan yang signifikan antara lama otore dengan ambang dengar penderita OMSK dengan kolesteatoma, karena keeratan hubungan antara 2 variabel ini tergolong lemah. Hal ini menunjukkan bahwa semakin lama otore belum tentu diikuti peningkatan rerata ambang dengar penderita OMSK dengan kolesteatoma.

Karakteristik sampel penelitian berdasarkan komplikasi OMSK dengan kolesteatoma sebelum operasi, didapatkan kasus terbanyak adalah tanpa komplikasi sejumlah 8 kasus $(57,2 \%)$.

\section{DISKUSI}

Pada penelitian kami distribusi jenis kelamin penderita OMSK dengan kolesteatoma yang menjalani mastoidektomi radikal lebih banyak perempuan 8 kasus (57,2\%) sedangkan laki-laki 6 orang (42,8\%). Penelitian yang dilakukan Arjana dikutip dari Hendro, ${ }^{5}$ terhadap 86 penderita OMSK tipe maligna yang dilakukan mastoidektomi radikal terdapat 52 kasus $(60,5 \%)$ laki-laki dan 34 kasus $(39,5 \%)$ perempuan. Krisnabudhi, dikutip dari Hendro, ${ }^{5}$ melakukan penelitian pada 45 penderita OMSK tipe maligna yang dilakukan mastoidektomi radikal dengan sebaran jenis kelamin laki-laki 26 penderita $(57,8 \%)$ dan perempuan 19 kasus $(42,2 \%)$.

Penderita yang tercakup dalam penelitian ini berumur 10-56 tahun dengan frekuensi tertinggi dijumpai pada umur 11-20 tahun dan umur 31-40 tahun masing-masing sejumlah 4 kasus $(28,6 \%)$. Frekuensi terendah pada kelompok umur kurang dari 10 tahun dan lebih dari 50 tahun masing-masing sejumlah 1 kasus (7,1\%). Kelompok umur OMSK dengan kolesteatoma yang dilakukan mastoidektomi bervariasi seperti dilaporkan peneliti sebelumnya yaitu Arjana, dikutip dari Hendro, ${ }^{5}$ terhadap 86 penderita OMSK tipe maligna yang dilakukan mastoidektomi radikal, didapatkan 22 kasus $(25,6 \%)$ pada umur $<16$ tahun dan 64 kasus $(74,4 \%)$ pada umur $\geq 16$ tahun. Sedangkan pada penelitian yang dilakukan oleh Krisnabudhi, dikutip dari Hendro, ${ }^{5}$ terhadap 45 penderita OMSK tipe maligna yang dilakukan mastoidektomi radikal didapatkan 10 kasus $(22,2 \%)$ pada umur $<14$ tahun dan 35 kasus $(77,8 \%)$ pada umur $\geq 14$ tahun.

Pada penelitian ini didapatkan 12 kasus (85,6\%) yang memiliki hasil operasi kering dan 2 kasus $(14,4 \%)$ basah pada evaluasi 2 bulan setelah operasi. Keluhan lama otore penderita OMSK dengan kolesteatoma yang dilakukan mastoidektomi radikal berlangsung dalam rentang waktu 3 bulan-18 tahun. Kasus terbanyak ditemukan pada kelompok lama otore 1-5 tahun sejumlah 7 kasus $(50,0 \%)$ dan kelompok yang paling sedikit jumlahnya pada kelompok umur $>10$ tahun sejumlah 1 kasus $(7,2 \%)$.

Penelitian yang dilakukan oleh Hendro ${ }^{5}$ terhadap 54 penderita OMSK dengan kolesteatoma memiliki rentang waktu lama otore 1-36 tahun dan yang paling banyak 
pada kelompok umur 1-5 tahun sejumlah 20 kasus $(37 \%)$. Penelitian Herdiana ${ }^{6}$ terhadap 11 penderita OMSK tipe maligna di RSUP Dr. Hasan Sadikin, Bandung didapatkan kasus dengan lama otore 1-10 tahun dengan jumlah kasus terbanyak pada rentang waktu 1-5 tahun sejumlah 6 sampel $(54,5 \%)$.

Lamanya keluhan otore menunjukkan waktu penyakit berjalan. Selama rentang waktu tersebut terjadi proses inflamasi yang melepaskan berbagai mediator-mediator inflamasi. Sitokin proinflamasi memegang peran penting dalam meningkatkan produksi mukus goblet telinga tengah. Selain itu terjadi peningkatan aktivitas transpor sodium potasium klorida dan menghambat transpor cairan pada channel $\mathrm{Na}+$ sehingga cairan menumpuk di telinga tengah dan memperberat otitis media. Terjadi stimulasi sekresi glikoprotein mukus yang diperantarai oleh metabolisme asam arakidonat dan menghambat pembersihan mukosilier. Keadaan ini dapat menyebabkan disfungsi mukosilier pada telinga tengah, sehingga terjadi penumpukan mukus di telinga tengah.

Berdasarkan hasil pemeriksaan otoskopi dan laporan operasi mastoidektomi radikal didapatkan lokasi perforasi dengan kasus terbanyak adalah perforasi total sejumlah 6 kasus (42,6\%), dan diikuti pada kelompok perforasi atik sejumlah 5 kasus $(35,8 \%)$, serta paling sedikit pada perforasi subtotal yaitu 3 kasus $(21,6 \%)$. Perforasi membran timpani pada penderita OMSK terjadi karena edema yang hebat pada mukosa telinga tengah dan hancurnya sel epitel superfisial, serta terbentuknya eksudat yang purulen di kavum timpani menyebabkan tekanan yang tinggi dalam ruang telinga tengah, sehingga mendorong pars tensa membran timpani kearah liang telinga luar. Apabila tekanan eksudat tidak berkurang, maka terjadi iskemia, akibat tekanan pada kapiler-kapiler, serta timbul tromboflebitis pada vena-vena kecil dan nekrosis mukosa dan submukosa. Hal inilah yang mengakibatkan rupturnya membran timpani sehingga eksudat keluar ke liang telinga luar. Yamamoto et al. ${ }^{8}$ mengklasifikasikan luas perforasi membran timpani dalam penelitiannya sebagai perforasi total adalah tanpa sisa membran timpani, besar bila perforasi pada lebih dari 3 kuadran, medium bila melibatkan 2 kuadran, kecil hanya 1 kuadran. Hasil penelitiannya pada OMSK dengan kolesteatoma adalah 90\% ditemukan luas perforasi diatas medium.

Pemeriksaan foto mastoid (Schuller) memungkinkan untuk melihat pneumatisasi mastoid, proses di dalamnya serta keadaan sinus lateralis. Kolesteatoma merupakan massa hasil penumpukkan dari deskuamasi lapisan keratin epitel skuamosa mukosa kavum timpani dan mastoid yang sebelumnya mengalami metaplasi, dan dapat mendestruksi tulang sekitarnya, jadi pada foto mastoid tampak sebagai gambaran destruksi tulang. ${ }^{9}$ Sebelum operasi, dilakukan pemeriksaan penunjang secara radiologis dengan foto Schuller dan CT scan. Dari sebanyak 14 sampel penderita OMSK dengan kolesteatoma didapatkan adanya gambaran kolesteatoma di foto Schuller pada 4 penderita, gambaran sklerotik pada 14 penderita dan satu penderita dilakukan $C T$ scan karena mengalami komplikasi abses Bezold. Adanya gambaran radiolusen menunjukkan adanya destruksi tulang sekitarnya oleh jaringan patologis.

Kolesteatoma di ruang telinga tengah dapat menyebabkan gangguan pendengaran dengan cara menghambat mobilitas osikel sehingga terjadi tuli konduksi. Perforasi pada umumnya menyebabkan tuli konduktif tidak lebih dari 15-20 dB, sedangkan apabila perforasi disertai kerusakan rangkaian tulangtulang pendengaran dapat menyebabkan tuli konduktif 30-50 dB. Bila terjadi diskontinuitas rangkaian tulang pendengaran di belakang membran yang masih utuh dapat menyebabkan tuli konduktif 55-65 dB. ${ }^{10}$

Kerusakan koklea pada pasien dengan OMSK dapat disebabkan oleh mediator inflamasi oleh kolesteatoma dan toksin 
bakteri yang masuk melalui membran tingkap bundar. Hal ini menyebabkan perubahan biokimia pada perilimfe dan endolimfe sehingga menyebabkan kerusakan dari organ korti. Aliran makromolekul seperti protein pada perilimfe lebih rentan terjadi pada keadaan inflamasi telinga tengah, karena meningkatnya permeabilitas vaskuler. Kerusakan terjadi pada sel rambut koklea, terutama yang terdapat pada basis koklea sehingga sel rambut menjadi sensitif terhadap suara berfrekuensi tinggi dan timbul tuli sensorineural. ${ }^{11}$

Penelitian oleh Samosir dkk. ${ }^{12}$ terhadap 53 penderita OMSK dengan kolesteatoma menemukan $84,8 \%$ tuli campur dan $48,1 \%$ tuli konduksi. Penelitian ini menyimpulkan bahwa kolesteatoma berhubungan dengan jenis tuli dan kolesteatoma meningkatkan risiko terjadinya jenis tuli campur menjadi 6 kali dibandingkan tanpa kolesteatoma pada pasien OMSK.

Berdasarkan derajat tuli pada penderita OMSK dengan kolesteatoma yang pemeriksaannya dilakukan sebelum operasi mastoidektomi radikal, terdapat hasil terbanyak adalah derajat tuli sedang sejumlah 6 kasus (46,1\%), sedangkan derajat tuli setelah operasi terbanyak pada derajat berat sejumlah 4 kasus $(33,3 \%)$. Penelitian yang dilakukan oleh Samosir dkk. ${ }^{12}$ terhadap 53 penderita OMSK dengan kolesteatoma didapatkan $86,2 \%$ tuli derajat berat-sangat berat dan $50 \%$ tuli derajat ringan-sedang, dengan kesimpulan kolesteatoma berhubungan signifikan terhadap derajat tuli. Kolesteatoma pada kasus OMSK meningkatkan risiko perburukan derajat tuli berat menjadi 7 kali dibandingkan tanpa kolesteatoma. De Azevedo et al. ${ }^{13}$ pada penelitiannya terhadap 115 penderita OMSK dengan dan tanpa kolesteatoma, mendapatkan 78 penderita OMSK dengan kolesteatoma dan sebanyak 15 penderita (13\%) mengalami tuli sensorineural.Yoshida et al. ${ }^{14}$ mengevaluasi 195 kasus tuli sensorineural dan melaporkan bahwa tuli sensorineural tidak dipengaruhi oleh umur penderita saat mulai menderita OMSK, tetapi berhubungan dengan lamanya gejala penyakit berlangsung. Namun pada penelitiannya dengan hasil uji Spearman $(\mathrm{r}=0,408, \mathrm{p}=0,166)$ menunjukkan bahwa tidak ada hubungan yang signifikan antara lama otore dengan ambang dengar penderita OMSK dengan kolesteatoma. Penelitian oleh Kaur, ${ }^{15}$ menunjukkan bahwa insiden tuli sensorineural (gangguan hantaran tulang) sebesar $13,64 \%$ bila lama penyakit kurang dari 5 tahun, dan meningkat menjadi 33\% bila lama penyakit lebih dari 26 tahun.

Pada penelitian Juhn et al. ${ }^{7}$ penderita OMSK dengan kolesteatoma yang menjalani mastoidektomi radikal, terdapat 6 penderita yang mengalami komplikasi ekstrakranial yaitu 5 penderita mengalami komplikasi abses subperiosteal dan 1 penderita abses Bezold. Komplikasi dapat timbul bila pertahanan telinga tengah dilewati sehingga memungkinkan infeksi menjalar ke struktur sekitarnya. Penyebaran dapat secara hematogen atau erosi tulang. Penderita dengan komplikasi ekstrakranial (abses subperiosteal) pada laporan operasi didapatkan planum mastoid telah destruksi sebagian.

Derajat kolesteatoma dinilai saat pemeriksaan otoskopi dan saat pembedahan dengan melihat penyebaran kolesteatoma di kavum timpani dan di kavum mastoid serta ditentukan dengan ada tidaknya komplikasi ekstra maupun intrakranial sesuai klasifikasi sistem TMC pada kolesteatoma oleh Belal. ${ }^{16}$

Pada penelitian kami ditemukan 2 jenis derajat kolesteatoma yaitu derajat 3 dan 4 dengan dengan jumlah kasus yang sama yaitu masing-masing sebanyak 7 kasus (50\%). Begitu pula jumlah kasus hasil operasi baik telinga kering maupun basah memiliki perbandingan jumlah yang sama yaitu masing-masing sebanyak 6 kasus $(42,8 \%)$ untuk hasil operasi telinga kering dan 1 kasus $(7,2 \%)$ hasil operasi telinga basah. Pada kolesteatoma derajat 4 dalam 
penelitian ini ditemukan kolesteatoma pada seluruh kavum timpani dan kavum mastoid dengan ditemukan 6 kasus dengan komplikasi ekstrakranial (5 abses subperiosteal dan 1 abses Bezold) dan 1 kasus tanpa komplikasi. Sedangkan pada kolesteatoma derajat 3 ditemukan kolesteatoma pada 2 lokasi di kavum timpani yaitu di epi atau meso atau hipotimpanum, serta ditemukan kolesteatoma pada antrum mastoid. Pada kolesteatoma derajat 3 ini seluruh kasus tidak ditemukan komplikasi OMSK.

Berdasarkan hasil uji Fisher Exact Test diketahui derajat kolesteatoma penderita OMSK dengan kolesteatoma yang dilakukan mastoidektomi radikal tidak menunjukkan hubungan yang signifikan dengan keberhasilan operasi nilai $\mathrm{p}=1,000(>0,05)$.

Kolesteatoma merupakan lesi keratin non neoplastik yang berhubungan dengan proliferasi sel epitel dengan karakteristik morfologi yang menyimpang. Patofisiologi penyebab timbulnya kolesteatoma belum diketahui secara pasti dan seutuhnya, namun diketahui bahwa kolesteatoma merupakan epitel skuamosa bertingkat yang terperangkap dalam kavum timpani. Oleh karena itu jenis operasi sebagai usaha untuk membersihkan kolesteatoma dan perawatan pasca bedah menjadi hal penting yang perlu diperhatikan agar memperolah hasil operasi yang baik. ${ }^{17}$

Kriteria keberhasilan operasi kolesteatoma adalah telinga kering, yaitu bila tidak didapatkan sekresi, tidak terdapat residual kolesteatoma dan epitelisasi lengkap. Sebaliknya, telinga yang masih tetap basah atau otore menetap pasca pembedahan merupakan salah satu tanda kegagalan bagi tercapainya tujuan pembedahan.

Pada penelitian kami, kondisi tulang pendengaran yang diperiksa saat dilakukan pembedahan (mastoidektomi radikal) didapatkan hasil kelompok kasus terbanyak yaitu kelompok sisa osikel maleus inkus stapes sebanyak 7 kasus $(50,0 \%)$. Penelitian oleh Wilsen dkk. ${ }^{10}$ terhadap 40 penderita OMSK dengan kolesteatoma saat dilakukan pembedahan, paling sering ditemukan hanya tersisa basis stapes yaitu sebanyak $67,5 \%$, diikuti dengan rantai tulang pendengaran yang utuh sebanyak $25 \%$.

Penelitian oleh Yamamoto et al. ${ }^{8}$ menunjukkan bahwa bagian osikel yang pertama kali mengalami kerusakan oleh kolesteatoma adalah manubrium maleus. Hal ini karena awal mula pertumbuhan kolesteatoma adalah masuknya sel epitel kulit melalui bagian superior perforasi membran timpani di daerah manubrium. Area ini kaya akan pembuluh darah kapiler sehingga epitel kulit yang terperangkap dapat tumbuh menjadi kolesteatoma.

Pada penelitian kami, evaluasi pasca operasi didapatkan telinga kering 12 kasus $(85,6 \%)$ dan telinga basah 2 kasus $(14,4 \%)$. Hasil penelitian ini tidak berbeda jauh dengan Vartiainen, ${ }^{18}$ yang melakukan evaluasi terhadap 136 telinga 10 tahun pasca operasi mastoidektomi dinding runtuh. Hasilnya 98\% telinga kering dan 2\% telinga basah.

Keberhasilan tindakan operasi dipengaruhi keterampilan operator, teknik pembedahan saat operasi, dan perawatan pasca bedah berupa peralatan yang steril serta penyuluhan kepada penderita atau keluarga penderita. Perawatan pasca bedah yang baik bertujuan agar proses epitelisasi dapat berjalan tanpa ada hambatan dan mekanisme pembersihan (self cleaning) menjadi lancar serta infeksi dapat dihindari. Perawatan yang baik idealnya dilakukan seaseptik mungkin dan dilakukan menggunakan mikroskop operasi. $^{18}$

Kolesteatoma residu terjadi sebagai hasil dari prosedur operasi yang tidak dapat mengangkat seluruh kolesteatoma, biasanya sisa kolestetaoma terletak pada retrotimpani dan atik anterior. Sedangkan kolesteatoma rekuren merupakan pertumbuhan baru kolesteatoma setelah dilakukan operasi pembersihan dan pertumbuhan tersebut 
muncul dari kantong mukosa yang tertarik (retraction pocket) dan mukosa polipoid. ${ }^{19}$

Faktor-faktor yang berhubungan dengan kolesteatoma residu dan rekuren menurut Arsovic, ${ }^{19}$ adalah letak kolesteatoma di meso dan retrotimpani sehingga sulit dijangkau, pertumbuhan mukosa ruang telinga tengah yang polipoid, dan kondisi yang menghambat mekanisme pembersihan.

Beberapa hal yang perlu diperhatikan untuk menghindari adanya kolesteatoma residual maupun rekuren adalah:

1. Pembuatan meatal flap (meatoplasti), yang bertujuan adalah agar mekanisme pembersihan (self cleaning) tidak terhalang, sehingga membuat perawatan pasca bedah menjadi lebih efektif.

2. Facial ridge harus direndahkan sampai setinggi kanalis semisirkularis lateralis dan nervus fasialis. Facial ridge yang tinggi akan menghalangi mekanisme pembersihan ke arah telinga luar, sehingga terjadi penumpukan debris yang akan menjadi media pertumbuhan kuman penyebab infeksi sehingga kavum mastoid tetap basah .

3. Kavitas, semakin besar kavitas yang terbentuk akibat tindakan pembedahan menyebabkan penyembuhan berlangsung lebih lama, resiko terjadinya infeksi pasca bedah menjadi lebih besar. Untuk mengurangi kavitas yang terlalu luas dilakukan pelandaian atau merendahkan tepi kavum mastoid.

4. Ujung mastoid (tip), bila masih menggaung akan menyulitkan dalam mekanisme pembersihan secara spontan karena terdapat bagian yang lebih rendah dari liang telinga. Untuk mengatasi hal tersebut adalah dengan melakukan amputasi terhadap ujung mastoid yang akan menyebabkan obliterasi pada bagian tersebut karena jaringan di atasnya akan kolaps ke dalam.
5. Sel-sel mastoid, saat operasi harus dibersihkan seoptimal mungkin untuk mencegah timbulnya jaringan granulasi di atas sisa sel-sel tersebut. Pada saat revisi pasca operasi didapatkan lokasi tersering adalah di daerah tegmen dan sudut sinodural.

6. Telinga tengah, terjadinya epitelisasi yang belum lengkap dan adanya infeksi di daerah tersebut.

7. Obliterasi mastoid, idealnya dilakukan pada saat operasi mastoidektomi dinding runtuh, namun dapat juga dilakukan pada saat revisi. Tujuan obliterasi mastoid adalah memperkecil kavitas yang terbentuk sehingga penyembuhan tidak terlalu lama. Obliterasi dapat menggunakan bone chip, kartilago, fasia, jaringan otot dan hidroksiapatit. ${ }^{19}$

Penelitian ini mendapatkan bahwa derajat kolesteatoma yang dilihat dari letak kolesteatoma pada kavum timpani dan kavum mastoid, serta ada tidaknya komplikasi ekstra ataupun intrakranial sesuai kriteria TMC oleh Belal, tidak memiliki hubungan dengan keberhasilan mastoidektomi. Hal ini dapat dikarenakan dalam usaha eradikasi kolesteatoma lebih erat kaitannya dengan keterampilan operator dan teknik operasi yang dilakukan sehingga dapat membersihkan seluruh kolesteatoma dalam tulang temporal.

\section{DAFTAR PUSTAKA}

1. Kadir,A. Saragih,AR. Hermani,B. Buku Acuan Oogi. Modul 1.5 Inflamasi Telinga Tengah. Kolegium Ilmu Kesehatan Telinga Hidung Tenggorok Bedah Kepala Leher. Edisi 2. 2015.

2. Kementrian Kesehatan Republik Indonesia. Buku 2 Riset Kesehatan Dasar 2013 dalam Angka. Indonesia Tahun 2013 Hal 426

3. Laporan Tahunan Malang : SMF Ilmu Kesehatan THT-KL RSU Dr. Saiful Anwar. 2017 dan 2018. Hal 1-5. 
4. Fitri, S.B. \& Taufiq, B. Tesis: Angka Keberhasilan Miringoplasti pada Perforasi Membran Timpani Kecil, Besar dan Subtotal pada Bulan Juni 2003 Sampai Juni 2004. Bandung: FK UNPAD. 2004.

5. Hendro DP. Tesis: Perbedaan Tingkat Kolesteatom Berdasarkan Jenis Bakteri Aerob Penyebab Infeksi Pada Penderita Otitis Media Supuratif Kronik Tipe Maligna. Fakultas Kedokteran Universitas Brawijaya Malang. 2008.

6. Herdiana, Soeseno B. Meningitis Otogenik. Dalam: SupardjoH, Soeroso BS, Suprihati, Jogjaharto, dkk, editor. Kumpulan Naskah Ilmiah Kongres Nasional XII PERHATI; 2830 Oktober 1999; Semarang. Badan Penerbit Universitas Diponegoro; 1999. Hal. 795-806.

7. Juhn SK, Jung MK, Hoffman MD, Drew BR, Preciado DA, Sausen NJ, et al. The Role of Inflammatory Mediators in the Pathogenesis of Otitis Media and Sequelae. Clinical and Experimental Otorhinolaryngology. 2008:117-38.

8. Yamamoto K, Yaguchi Y, Kojima H. Clinical Analysis of Secondary Acquired Cholesteatoma. American Journal of Otolaryngology-Head and Neck Meicine and Surgery. 2014.

9. Pramesthi E, Ahadiah TH. Evaluasi Operasi Mastoidektomi Dinding Runtuh pada Penderita Otitis Media Supuratif Kronik Tipe Bahaya di RSUD dr. Soetomo Surabaya Januari 2007-Desember 2008. Jurnal Unair. 2010. pp 23-32.

10. Wilsen, Satria D, Doris Y, Ghanie A. Gambaran Audiologi dan Temuan Intraoperatif Otitis Media Supurtif Kronik Dengan Kolesteatoma pada Anak. Jurnal MKS. N0 2. 2014. Hal 124-7.

11. Wahyudiasih DP. Tesis: HubunganJenis Bakteri Aerob dengan Resiko Tuli Sensorineural Penderita Otitis Media Supuratif Kronis yang Dilakukan Mastoidektomi di RSUD dr. Saiful Anwar Malang 1 Januari 2005 - 31 Desember 2010. Malang: FK UB.2011.

12. Samosir I, Suprihati, Naftali Z. Hubungan Kolesteatoma dengan Jenis dan Derajat Kurang Pendengaran pada Pasien Otitis Media Supuratif Kronik. Jurnal Kedokteran Diponegoro. Semarang. 2018 (7)2 hal: 56273.
13. De Azevedo AF, De castro Soares AB, Garchet HQC. Tympanomastoidectomy: Comparison between canal wall-down and canal wall-up techniques in surgery for chronic otitis media. Int. Arch. Otorhinolaryngol. 2013;17(3):242-5.

14. Yoshida H, Miyamoto I, Takahashi H. Is Sensorineural Hearing loss with Chronic Otitis Media Due to Infection or Aging in Older Patients? Auris Nasus Larynx .International journal of ORL \& HNS 2010; 37(3):269-73.

15. Kaur K, Sonkhya N, Bapna AS. Chronic Suppurative Otitis Media and Sensorineural Hearing Loss : Is There A Correlation. Indian Journal of Otolaryngology and Head and Neck Surgery. 2003 55(1):21-4.

16. Belal A, Reda M, Mehana A and Belal Y. A New Staging System for Tympano-mastoid Cholesteatoma. The Journal of International Advanced Otology. 2012; 8(1): 63-8.

17. Frickmann $\mathrm{H}$ and Zautner AE. Cholesteatoma - A Potential Consequence of Chronic Middle Ear Inflammation. Otolaryngology. 2012; S5(001): 1-8.

18. Vartiainen E. Ten yYear Results of Canal Wall Down Mastoidectomy for Acquired Cholesteatoma. Auris Nasus Larynx (2000) ; 27; pp 227-9.

19. Arsovic N, Djeric D, Petrovic Z, et al. Ethiophatogenetic aspect of Reccurent Cholesteatoma Development. International Congress Series 1240 (2003) hal 37-42.124. 